\title{
Clinical and anatomopathological descriptions of dog with arterious Hemitruncus: case report
}

\author{
[Descrições clínicas e anatomopatológicas de cão com \\ hemitruncus arterioso: relato de caso \\ J.C. Barros ${ }^{1}$, D. Paulino Júnior ${ }^{1}$, T.H.C. Sasahara ${ }^{2}$, L.F. Magalhães ${ }^{1}$, \\ A.R. Oliveira ${ }^{3}$ W.T. Blanca ${ }^{1}$; F.G.G. Dias ${ }^{1 *}$ \\ ${ }^{1}$ Universidade de Franca (Unifran) - Franca, SP \\ ${ }^{2}$ Universidade de São Paulo - São Paulo, SP \\ ${ }^{3}$ Aluno de pós-graduação - Universidade de Franca (Unifran) - Franca, SP
}

\begin{abstract}
The anomalous origin of the pulmonary trunk in the ascending aorta, defined as arterious hemitruncus, is a rare congenital malformation in dogs, caused by a defect in the spiral septum. Thus, given the unusual occurrence in the canine species, the systemic severity and the high lethality, the aim of this study was to describe this heart disease in a three-month-old male German Spitz puppy, emphasizing clinical changes of the necropsy and microscopics. The animal had cyanosis, dyspnea and weakness and was forwarded for necropsy after sudden death. Numerous changes were detected in the post-mortem examination, including in the heart, as cardiomegaly and absence of the arterial ligament, which was replaced by the complete fusion between the ascending aorta and the pulmonary trunk, after leaving both the left and right ventricles, respectively and, among the microscopic findings, cardiomyocyte hypertrophy stood out. The association of these findings with the history indicated the diagnosis of arterious hemitruncus followed by cardiorespiratory failure, emphasizing the importance of out complementary cardiological exams in young symptomatic patients for the survival of those affected. Arterious hemitruncus, although rare, must be added in the differential diagnosis of other heart diseases that cause similar clinical signs.
\end{abstract}

Keywords: canine specie, cardiac malformation, cardiovascular system, congenital anomaly

\section{RESUMO}

A origem anômala do tronco pulmonar em aorta ascendente, definida como hemitruncus arterioso, é uma malformação congênita rara em cães, causada por defeito no septo espiral. Assim, diante da ocorrência incomum na espécie canina, da gravidade sistêmica e da alta letalidade, o objetivo deste trabalho foi descrever essa doença cardíaca em um filhote de três meses de idade, macho, Spitz Alemão, enfatizando as alterações clínicas, de necropsia e microscópicas. $O$ animal apresentava cianose, dispneia e fraqueza e foi encaminhado para necropsia após morte súbita. Inúmeras alterações foram detectadas no exame postmortem, inclusive no coração, como cardiomegalia e ausência do ligamento arterioso, o qual foi substituído pela fusão completa entre aorta ascendente e tronco pulmonar, após a saída de ambas dos ventrículos esquerdo e direito, respectivamente, e, dentre os achados microscópicos, destacou-se a hipertrofia de cardiomiócitos. A associação desses achados com o histórico indicou o diagnóstico de hemitruncus arterioso seguido de insuficiência cardiorrespiratória, ressaltando-se a importância de exames complementares cardiológicos em pacientes jovens sintomáticos na sobrevida dos acometidos. $O$ hemitruncus arterioso, apesar de raro, deve ser acrescido no diagnóstico diferencial de outras cardiopatias que causam sinais clínicos similares.

Palavras-chave: espécie canina, malformação cardíaca, sistema cardiovascular, anomalia congênita

Recebido em 29 de julho de 2020

Aceito em 14 de dezembro de 2020

*Autor para correspondência (corresponding author)

E-mail: fernandagosuen@yahoo.com.br 


\section{INTRODUCTION}

Arterious hemitruncus is characterized by the fusion of the pulmonary trunk with the ascending aorta due to a defect in the spiral septum, which divides the fetal trunk into the arteries, pulmonary and aorta, during intrauterine growth (UrbinaVazquez et al., 2020). The absence of this septation in the embryological trunk, through the infundibulum's trunk ridges, generates a single artery that arises from the base of the heart, supplying the systemic, pulmonary and coronary blood flows (Schwarzwald et al., 2003; Nicolle et al., 2005). It is considered an unusual cardiac malformation in humans (Nathan et al., 2007; Urbina-Vazquez et al., 2020), corresponding to $0.1 \%$ of all congenital cardiovascular anomalies (Koplay et al., 2012). In domestic animals, it is rare, being described in the scientific literature in cat (Nicolle et al., 2005; Chuzel et al., 2007), calf (Schwarzwald et al., 2003) and dog (Scollan et al., 2011).

In affected patients, the lung connected to the pulmonary trunk of anomalous origin receives overload of blood volume and pressure from the left ventricle, causing vasoconstriction followed by pulmonary hypertension (Urbina-Vazquez et al., 2020), in addition to congestive heart failure, which together can progress rapidly to low blood oxygenation of the tissues and consequently death of the animal (Haywood et al., 2014). Clinical signs presented by human and animal patients are varied, but they usually include dyspnea, murmur (Scollan et al., 2011; Haywood et al., 2014), cyanosis, lethargy, tachypnea, tachycardia (Chuzel et al., 2007; Koplay et al., 2012) and cough, usually already in the first year of life (Urbina-Vazquez et al., 2020).

The diagnosis of arterious hemitruncus should be based on the patient's history, clinical symptoms and complementary exams invasive or not (Scollan et al., 2011; Koplay et al., 2012; Mahan et al., 2016). In this context, chest $\mathrm{x}$-rays may suggest moderate cardiomegaly and peribronchial thickening (Koplay et al., 2012); echocardiogram shows cardiac hypertrophy, increased ventricular pressure and pulmonary trunk stenosis (Scollan et al., 2011); thoracic computed tomography will propose the anomalous origin of the pulmonary artery (right or left) of the ascending aorta and cardiac magnetic resonance imaging to elucidate the pulmonary trunk arising from the aorta, in addition to increased cardiac pressure (increased atrium and affected ventricle), sharp decrease in ventricular function, pulmonary and tricuspid valve regurgitation (Scollan et al., 2011; UrbinaVazquez et al., 2020). In addition, cardiac catheterization causes vascular obstructions, in addition to valve and myocardial functioning (Haywood et al., 2014); angiography provides precision in the pressure measurements of the great vessels, as well as of the cardiac cavities (Urbina-Vazquez et al., 2020) and computed angiotomography or magnetic resonance to define the presence of the anomalous pulmonary trunk, originating from the descending aorta (Haywood et al., 2014).

Both in animals (Chuzel et al., 2007; Scollan et al., 2011) as in humans (Mahan et al., 2016; Urbina-Vazquez et al., 2020), the early corrective treatment of choice for arterious hemitruncus is surgical, covering various techniques, to avoid fatalities due to the irreversibility of pulmonary hypertension and congestive heart failure. However, some patients cannot survive until the execution of such a procedure and transoperative complications are likely to occur, as immediate postoperative risks (Scollan et al., 2011).

In view of the rare occurrence of arterious hemitruncus in animals, the aim of this study was to report a case of this congenital heart disease in the canine specie, highlighting the clinical, of the necropsy and microscopic characteristics. In addition, it aims to raise awareness among veterinarians and guardians about the importance of complementary cardiological exams in symptomatic young patients, since early therapeutic intervention can improve the quality of life and the survival rate of affected patients.

\section{CASE REPORT}

A canine three-month-old German Spitz breed, male puppy, was referred by a veterinary colleague to the Animal Pathology sector of the Veterinary Hospital of the University of Franca for necroscopic examination after sudden death. According to the tutor's information, the animal presented cyanosis after exercise, dyspnea and weakness, and no complementary hematological or imaging tests were performed.

At necropsy, macroscopic changes were identified in the oral mucosa (cyanosis), lungs 
(95\% of the reddish parenchyma, blood flowing at the cut and presenting hypocrepitant), spleen (slight splenomegaly), liver (hepatomegaly, friable, with pale areas alternating to blackish, flowing blood at the cut), stomach (reddish mucosa), intestine (pale intestinal serosa), mesenteric lymph nodes (enlarged and reddish in color), kidneys (intensely reddish medullary), brain (tearing of the grooves, in addition to petechiae and suffusions in the frontal region of the cerebral hemispheres), besides cardiac changes. With regard to cardiac involvements, these were directly related to the organ's morphology. Externally, there was a globose heart with eccentric hypertrophy of the left ventricle, besides significant dilation of the right ventricle, especially in the region of the arterious cone.

At the base of the organ, there was an absence of the arterious ligament, which was replaced by the complete fusion between the ascending aorta and the pulmonary trunk, right after leaving both the left and right ventricles, respectively (Figure 1A). Internally, the separate aortic and pulmonary valves were noted and the presence of a membrane partially dividing the outlet of both vessels, but with subsequent complete fusion, giving rise to only a calibrated vessel (Figure 1B).

Microscopically, pulmonary changes were observed (marked congestion, moderate diffuse edema, slight amount of fibrin inside the alveoli, discreet emphysema and thickening of the alveolar septum), splenics (extramedullary hematopoiesis and lymphoid reactivity), hepatics (hemorrhage focus, marked degeneration of hepatocytes, congestion, mild cholestasis and moderate necrosis), gastric (gastric pit hyperplasia), intestinal (calciform cells hypertrophy, moderate mixed infiltrate (lymphocytes and eosinophils) in own blade and reactivity of Peyer plates), in lymphnodes (lymphoid reactivity), kidneys (discrete areas of hemorrhage in the cortex, moderate degeneration and tubular necrosis and membranous glomerulonephritis), brain (areas of hemorrhage, hyperemia and neuronal death) and cardiacs (hypertrophy of cardiomyocytes).
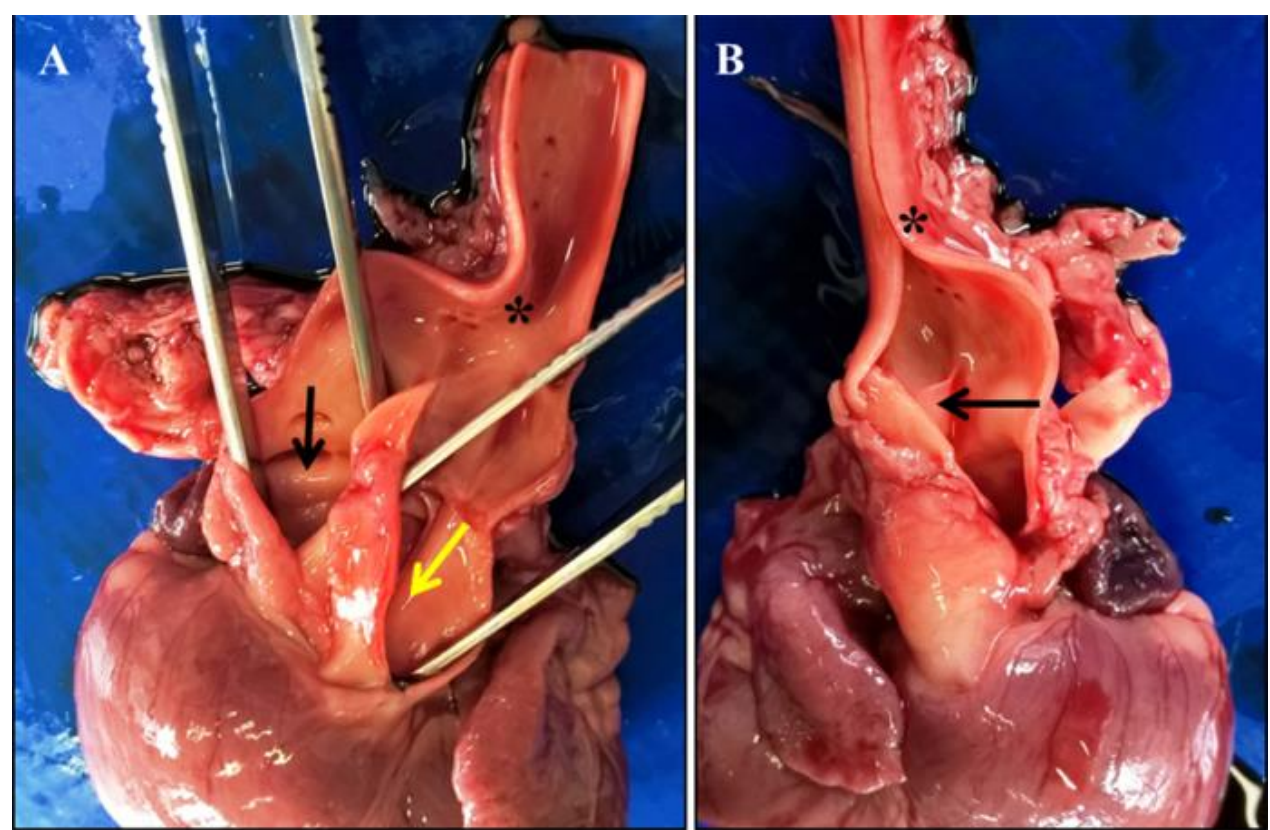

Figure 1. Heart necropsy images of a German Spitz puppy dog, three-month-old, with the presence of hemitruncus. A: Complete fusion (*) between ascending aorta artery (black arrow) and pulmonary trunk (yellow arrow), right after leaving both the left and right ventricles, respectively. B: Membrane partially dividing the outlet of both vessels (black arrow), but with subsequent complete fusion, giving rise to only one calibrated vessel (*). 
Necropsy findings, especially the cardiovascular, together with the patient's history, defined the diagnosis of arterious hemitruncus and the cause of death as cardiorespiratory failure and, the microscopic results showed changes secondary to the referred congenital cardiovascular anomaly.

\section{DISCUSSION}

The fact that arterious hemitruncus is rare in the canine specie (Scollan et al., 2011), makes it difficult to standardize factors such as etiology, sexual, age and racial predisposition, clinical symptoms, efficient therapeutic techniques, prognosis and, consequently, the comparison between the affected patients, making the discussion restricted and difficult. In this sense, despite the rarity of this congenital heart disease in dogs, the low prevalence described in the scientific literature can also be attributed to the non-request for cardiological and necroscopic examinations by veterinary professionals, to diagnostic failures and to an unfavorable prognosis due to the rapid progression of the disease to death. Thus, the importance of scientifically reporting cases such as the current work is emphasized.

In humans, according to Koplay et al. (2012) and Haywood et al. (2014), anomaly of the right pulmonary artery is more common than in the left, occurring on the posterior face of the ascending aorta, close to the aortic valve, corroborating with the dog diagnosed by Scollan et al. (2011), with the cats described by Nicolle et al. (2005) and by Chuzel et al. (2007) and with the necropsy findings of the patient in the present study. In this theme, the impairment in the left pulmonary artery originates from the descending aorta, associated with the aortic arch (Koplay et al., 2012). Although cardiac pathologies concomitant with arterious hemitruncus were not diagnosed in the canine patient of the current report, Haywood et al. (2014) argued that, in humans, joint occurrence with persistent ductus arteriosus, Tetralogy of Fallot, interatrial communication and ventricular septal defect is possible.

Although there are no scientific descriptions about the age predisposition of arterious hemitruncus in animals, the patient in the present report was a puppy (three months old), according to the four-month-old dog diagnosed by Scollan et al. (2011) and with the cats atended by Chuzel et al. (2007), with five months. These results are similarly described in human patients (Haywood et al., 2014; Mahan et al., 2016). In contrast, the cat described by Nicolle et al. (2005) was diagnosed when adult (six years old), despite being symptomatic from a young age. Regarding the German Spitz breed and the patient's gender of the present report, no similarity was observed with the female Pinscher mentioned by Scollan et al. (2011).

The clinical symptoms presented by dogs and cats with arterious hemitruncus are similar to those of human patients (Koplay et al., 2012; Haywood et al., 2014), with the exception of hemoptysis described in these latter (Urbina-Vazquez et al., 2020). According to Santos Júnior and collaborators (2007), the clinical manifestations of patients with congestive heart failure, and consequently their necropsy findings, they are justified by the activation of neurohumoral mechanisms throughout the pathophysiology of the disease.

\section{CONCLUSIONS}

In light of the reported case, it is admitted that, although rare, arterious hemitruncus should be included in the differential diagnosis of other heart diseases that cause similar clinical signs in dogs as in young cats as the aorticopulmonary septal defect.

\section{ACKNOWLEDGEMENTS}

Coordenação de Aperfeiçoamento de Pessoal de Nível Superior - Brasil (CAPES).

\section{REFERENCES}

CHUZEL, T.; BUBLOT, I.; COUTURIER, L. et al. Persistent truncus arteriosus in a cat. J. Vet. Cardiol., v.9, p.43-46, 2007.

HAYWOOD, L.J.; CHAKRYAN, Y.; KIM, D. et al. Abnormal origin of the right pulmonar artery from ascending aorta (Hemitruncus arteriosus). J. Investig. Med. High Impact Case Rep., v.27, p.13, 2014.

KOPLAY, M.; EROL, C.; PAKSOY, Y. et al. Hemitruncus arteriosus: cardiac magnetic resonance angiography findings. Congenit. Heart Dis., v.7, p.66-69, 2012. 
MAHAN, V.L.; STEVENS, R.M.; MESIA, C.I. et al. The internal mammary artery as a shunt in a noncyanotic infant with hemitruncus: surgical and anesthetic management. J. Clin. Anesth., v.32, p.12-16, 2016.

NATHAN, M.; RIMMER, D.; PIERCEY, G. et al. Early repair of hemitruncus: excellent early and late outcomes. J. Thorac. Cardiovasc. Surg., v.133, p.1329-1335, 2007.

NICOLLE, A.P.; TESSIER-VETZEL, D.; BEGON, E. et al. Persistent truncus arteriosus in a 6-year-old cat. J. Vet. Med. A. Physiol. Pathol. Clin. Med., v.52, p.350-353, 2005.

SANTOS JÚNIOR, E.R.; MELO, A.N.; WISCHRAL, A. Fisiopatologia da insuficiência cardíaca e o uso do maleato de enalapril em cães. Ciênc. Vet. Tróp., v.10, p.1-8, 2007.
SCHWARZWALD, C.; GERSPACH, C.; GLAUS, T. et al. Persistent truncus arteriosus and patente foramen ovale in a Simmentaler $\mathrm{x}$ Braunvieh calf. Vet. Rec., v.152, p.329-333, 2003.

SCOLLAN, K.; SALINARDI, B.; BULMER, B.J. et al. Anomalous left-to-right shunting communication between the ascending aorta and right pulmonar artery in a dog. J. Vet. Cardiol., v.13, p.147-152, 2011.

URBINA-VAZQUEZ, A.; LOPEZRODRÍGUES, M.D.C.; ORTEGA-SILVA, S. et al. Multimodality imaging of the anomalous origin of the right pulmonary artery from the ascending aorta in an adult (hemitruncus arteriosus). J. Cardiovasc. Comput. Tomogr., v. 14, p. e89-e92, 2020. 